\title{
Knowledge, Attitudes and Perception of the Public on Female Genital Mutilation
}

\author{
Akintoye Emily Obaide ${ }^{1^{*}}$, Akintoye Onome Pearl and Adjene Josiah Obaghwarhievwo \\ *Correspondence author \\ Emily Obaide \\ ${ }^{1}$ Department of Public and Community Health, College of \\ Health Sciences, Novena University, Ogume, Delta State, \\ Nigeria \\ Department of Public and Community Health \\ College of Health Sciences \\ Novena University \\ Ogume \\ Delta State \\ Nigeria \\ Submitted : 16 Dec 2020 ; Published : 16 Jan 2021
}

\begin{abstract}
Despite global concerns, awareness, and campaigns against Female Genital Mutilation (FGM), prevalence remains high in most countries of the globe, especially Africa. Current study investigated the knowledge, attitude and public perception on FGM of Bini indigenes who reside in Oredo Local Government Area of Edo State, Southern Nigeria. A total of one hundred and fifty (150) participants were ethically recruited from Benin City, Nigeria. An open ended questionnaire of about the same number $(n=150)$ was carefully structured, validated and distributed to participants in order to ascertain their level of awareness and understanding of the socio-cultural implications of FGM. An oral interview was also conducted on participants to determine the effect of their level of education on possible promulgation of FGM within the study area. Sociodemographic data of respondents were also collected and comparisons made across gender, age and religious lines on beliefs and practices of FGM. Sections of the questionnaire were subjected to statistical analysis after data collection, results expressed in simple percentages. After careful observation, study found that about $74.5 \%$ of the respondents were ill-informed on the cultural norms and principles of FGM in line with global best practices of the World Health Organizations (WHO). However, not fewer than $36.3 \%$ of the respondents show adequate knowledge on the concept of FGM. Study also observed that a great percentage of educated respondents strongly opposed to the idea of FGM. This implies that educational health campaigns against FGM could be useful in combating the hazardous implications of FGM on the socio-cultural well-being of the female child. Continuous education geared towards global best practices in study area is highly recommended.
\end{abstract}

Keywords: Female Genital Mutilation, Knowledge, Attribute, Tradition

\section{Introduction}

Female genital mutilation [FGM] or Female circumcision or cutting $[\mathrm{FC}]$ is a practice that is common in several countries across the globe, especially Africa $[1,2]$. The World Health Organization (WHO) defines it as a procedure by which the female external genitalia are partially or totally removed with excruciating pain and injury to the female genital organs, either for cultural or non-therapeutic reasons [3].

In recent times, FGM practices are deeply rooted in gender disproportion, cultural exclusiveness, as well as in the beliefs and practices of purity, restraint, aesthetics, class and reputation. It acts as a testament for the control of women's libido and sexual desires, promoting fidelity and chastity, and is often encouraged by both women and men $[3,4]$.

It has been reported that the major components of African culture, norms and traditions vary across ethnic enclaves in diverse communities with observed procedures across ages

between six and eight, and a few cultures preferring it at birth, menarche, or before marriage [5]. Till recently, FGM is still in active practice across six states of Nigeria with relatively stable prevalence rates over time [6-8].

In Edo state for instance; where FGM and related practices was banned in October 1999, traditional sceptics have however condemned the ban, with some applauding it as a good step in the right direction. To this point, there exist a lacuna in an all-inclusive knowledge base on the socio-cultural response on FGM practicing communities in Nigeria and Edo State in particular, even with the recent legislations (Nigeria's 2015 VAPP Act) that calls for the elimination of FGM practices by 2030 , with no rigorous review and intervention models within the country [9]. A 2013 UNICEF report had earlier called for legislation against FGM in a vast majority of countries where it is practiced. It also calls for measures complementing this legislation and leveraging positive social dynamics for changing 
social norms. To this point, the UNICEF practice of FGM in Lagos state was very high (CWSI, 2016). Albeit, corroborating information could not be found among the sources consulted by available FGM-based Researches. Current study was therefore envisioned to provide a knowledge, attitudinal and perception for the effect of FGM on socio-cultural activities of the inhabitants of Oredo Local Government Area of Edo State, Nigeria.

\section{Aim of Study}

This study determined the knowledge, attitude and perception of FGM on the cultural norms and values of the residents of Oredo Local Government Area of Edo State, Nigeria. Specifically, the study;

1. Determined the socio-demographic properties of study are in relation to age, gender and religious beliefs on FGM

2. Examined of the FGM on the socio-cultural values of inhabitants of Ordo Local Government Area of Edo State.

3. Determined the effect of education on the promotion of FGM in the society

\section{Materials and Method}

Research Design: This study adopted the survey type of research design as it is exploratory in nature and consist of data gathering from a large number or respondents, strategically investigating and conceiving answers to research questions or problems.

Study Population: The population for this study comprises of Bini residents in Oredo Local Government Area of Edo State, literate and non - literates who are conversant with the cultural practices and norms of the ancient Benin kingdom as it relates to FGM.

Sample Size: A total of one hundred and fifty (150) participants (sample) were drawn from the population of Bini indigenes who were resident in Oredo Local Government Area of Edo State; the study area. This sample was drawn to reflect the various segment of the population without any form of bias.

Sampling Technique: Using the simple random sampling technique, this study selected a part of a population for the purpose of this Research, this method was adopted due to its relative ease and affordability, providing quick opportunity to pick from the entire population of study without any form of bias.

Method of Data Collection: Study adopted both primary and secondary methods of data collection. Basically, the primary method consists of the use of well-structured and validated questionnaire and in-depth interview. The gaps which existed after the administration of the questionnaires were filled with interview conducted during the study. Only personals with deep understanding of Bini traditions, who are possibly custodians of the Bini culture were interviewed. The secondary sources of data collection include Journal, books and articles
/ publications.

Analytical Approach: Obtained collected from respondents were subjected through statistical measures of central tendencies and average values (means) obtained after proper sorting. Data was then represented in frequency distribution table, analysed, interpreted and presented using simple percentage.

\section{Results}

\begin{tabular}{|c|c|c|c|}
\hline Variables & Attributes & Frequency & Percentage \\
\hline \multirow[t]{5}{*}{ Age } & $30-40$ & 122 & 57.5 \\
\hline & $40-50$ & 42 & 19.8 \\
\hline & $50-60$ & 28 & 13.2 \\
\hline & $60-70$ & 18 & 8.5 \\
\hline & 70 and above & 2 & 0.9 \\
\hline \multirow[t]{4}{*}{ Religion } & Christian & 148 & 69.8 \\
\hline & Muslim & 26 & 12.3 \\
\hline & Traditional & 36 & 17.0 \\
\hline & Others & 2 & 0.9 \\
\hline \multirow[t]{6}{*}{$\begin{array}{l}\text { Educational } \\
\text { qualification }\end{array}$} & $\begin{array}{l}\text { SSCE and } \\
\text { below }\end{array}$ & 56 & 26.4 \\
\hline & OND & 18 & 8.5 \\
\hline & HND & 28 & 13.2 \\
\hline & B.Sc. & 84 & 39.6 \\
\hline & M.Sc. & 20 & 9.4 \\
\hline & Ph.D. & 6 & 2.8 \\
\hline \multirow[t]{5}{*}{ Tribe } & Benin & 112 & 52.8 \\
\hline & Esan & 42 & 19.8 \\
\hline & Owan & 24 & 11.3 \\
\hline & Etsako & 16 & 7.5 \\
\hline & Others & 18 & 8.5 \\
\hline \multirow{5}{*}{$\begin{array}{l}\text { Residential } \\
\text { area }\end{array}$} & GRA & 14 & 6.6 \\
\hline & Ikpoba Okha & 2 & 0.9 \\
\hline & \begin{tabular}{|l|} 
Ologbo \\
\end{tabular} & 4 & 1.9 \\
\hline & \begin{tabular}{|l|} 
Oredo \\
\end{tabular} & 182 & 85.8 \\
\hline & Ughelli & 10 & 4.7 \\
\hline
\end{tabular}

Table 1: Biodata of respondents

\begin{tabular}{|l|l|l|l|}
\hline & & Frequency & Percentage \\
\hline $\begin{array}{l}\text { Do you } \\
\text { believe in } \\
\text { FGM }\end{array}$ & Yes & 92 & 43.4 \\
\cline { 2 - 4 } $\begin{array}{l}\text { Do you } \\
\text { know the } \\
\text { importance } \\
\text { of FGM on } \\
\text { the Benin } \\
\text { culture }\end{array}$ & Yos & 120 & 56.6 \\
\cline { 2 - 4 } & & 114 & 53.8 \\
\hline
\end{tabular}




\begin{tabular}{|c|c|c|c|}
\hline \multirow[b]{2}{*}{$\begin{array}{l}\text { Do you } \\
\text { believe that } \\
\text { the people } \\
\text { of Benin } \\
\text { respect their } \\
\text { culture more } \\
\text { than the } \\
\text { practice of } \\
\text { FGM }\end{array}$} & Yes & 160 & 75.5 \\
\hline & No & 52 & 24.5 \\
\hline \multirow{5}{*}{$\begin{array}{l}\text { What is the } \\
\text { relationship } \\
\text { b e t w e e } n \\
\text { FGM and } \\
\text { the Benin } \\
\text { culture }\end{array}$} & No response & 122 & 57.5 \\
\hline & CIRCUMCISION & 24 & 113 \\
\hline & IDENTITY & 6 & 2.8 \\
\hline & $\begin{array}{l}\text { NO } \\
\text { RELATIONSHIOP }\end{array}$ & 42 & 19.8 \\
\hline & $\begin{array}{l}\text { TO CONTROL } \\
\text { PROSTITUTION }\end{array}$ & 18 & 8.5 \\
\hline \multirow{2}{*}{$\begin{array}{l}\text { Despite the } \\
\text { importance } \\
\text { of FGM, od } \\
\text { the Benin } \\
\text { still practice } \\
\text { FGM }\end{array}$} & Yes & 120 & 56.6 \\
\hline & No & 92 & 43.4 \\
\hline
\end{tabular}

Table 2: Implications of FGM on Culture

\begin{tabular}{|c|c|c|c|}
\hline Variables & Attributes & Frequency & Percentage \\
\hline \multirow{3}{*}{$\begin{array}{l}\text { To what extent } \\
\text { are the Benin } \\
\text { ready to practice } \\
\text { FGM against their } \\
\text { culture }\end{array}$} & A large extent & 138 & 65.1 \\
\hline & $\begin{array}{l}\text { Very large } \\
\text { extent }\end{array}$ & 74 & 34.9 \\
\hline & $\begin{array}{l}\text { Extremely } \\
\text { large extent }\end{array}$ & 0 & 0.0 \\
\hline \multirow{3}{*}{$\begin{array}{l}\text { Do all Benin } \\
\text { believe in their } \\
\text { culture }\end{array}$} & Yes & 76 & 35.8 \\
\hline & No & 34 & 16.0 \\
\hline & Not fully & 102 & 48.1 \\
\hline \multirow{3}{*}{$\begin{array}{l}\text { Do all Benin give } \\
\text { their cooperation/ } \\
\text { consent during the } \\
\text { practice of FGM }\end{array}$} & Yes & 34 & 16.0 \\
\hline & No & 178 & 84.0 \\
\hline & Not fully & 0 & 0.0 \\
\hline \multirow{2}{*}{$\begin{array}{l}\text { Are the Benin } \\
\text { ready to forgo } \\
\text { their culture and } \\
\text { obey the practice } \\
\text { FGM }\end{array}$} & Yes & 50 & 23.6 \\
\hline & No & 162 & 76.4 \\
\hline \multirow{2}{*}{$\begin{array}{l}\text { Do the Benin } \\
\text { strongly belief in } \\
\text { their cultural value }\end{array}$} & Yes & 170 & 80.2 \\
\hline & No & 42 & 19.8 \\
\hline \multirow[b]{2}{*}{$\begin{array}{l}\text { Despite the } \\
\text { importance of } \\
\text { FGM, do the } \\
\text { Benin still want } \\
\text { to obey the FGM } \\
\text { or obeying their } \\
\text { culture }\end{array}$} & Yes & 116 & 54.7 \\
\hline & No & 96 & 45.3 \\
\hline
\end{tabular}

Table 3: Influence of Benin Culture on FGM Practice

\begin{tabular}{|c|c|c|}
\hline & Yes & No \\
\hline $\begin{array}{l}\text { Do the Benin that girls who are } \\
\text { circumcised are likely to be a } \\
\text { prostitute }\end{array}$ & $86(40.6)$ & $126(59.4)$ \\
\hline $\begin{array}{l}\text { Do you believe that girls who are } \\
\text { not circumcised enjoy sex }\end{array}$ & $94(44.3)$ & $118(55.7)$ \\
\hline $\begin{array}{l}\text { Do you believe that girls who are } \\
\text { circumcised enjoy sex }\end{array}$ & $62(29.2)$ & $150(70.8)$ \\
\hline $\begin{array}{l}\text { Do you believe that girls who } \\
\text { were not circumcise stay more in } \\
\text { their matrimonial home }\end{array}$ & $60(28.3)$ & $152(71.7)$ \\
\hline $\begin{array}{l}\text { Do girls from Benin culture have } \\
\text { any choice of being circumcised }\end{array}$ & $112(52.8)$ & $100(47.2)$ \\
\hline $\begin{array}{l}\text { Do the Benin parents believe } \\
\text { more in their culture rather than } \\
\text { the World Health Organization } \\
\text { about FGM }\end{array}$ & $134(63.2)$ & $78(36.8)$ \\
\hline $\begin{array}{l}\text { Do girls who are not circumcised } \\
\text { command respects in the society }\end{array}$ & $90(42.5)$ & $122(57.5)$ \\
\hline $\begin{array}{l}\text { As a girl, have you been } \\
\text { circumcised }\end{array}$ & $74(34.9)$ & $138(65.1)$ \\
\hline
\end{tabular}

Table 4: Social Implication of FGM on the Girl Child

\begin{tabular}{|l|l|l|}
\hline & Yes & No \\
\hline $\begin{array}{l}\text { Do you believe more in your } \\
\text { tradition rather than your education }\end{array}$ & $68(32.1)$ & $144(67.9)$ \\
\hline $\begin{array}{l}\text { With the level of education/ } \\
\text { awareness, do you still believe in } \\
\text { FGM practice }\end{array}$ & $56(26.4)$ & $156(73.6)$ \\
\hline $\begin{array}{l}\text { Does your educational qualification } \\
\text { change your belief about FGM }\end{array}$ & $108(50.9)$ & $104(49.1)$ \\
\hline
\end{tabular}

Table 5: Effect of Education FGM Beliefs and Practices

\section{Discussion}

As a common practice in several African countries, the introduction of female genital mutilation [FGM] has spark divergent debates to the creams of religious and socioeconomic practitioners across the globe. To the World Health Organization (WHO), be it for cultural, ethno-religious or non-therapeutic reasons, FGM is a painstaking procedure that involves partial and/or total removal of the external female genitalia with perturbed conscious injury to the female genital organs [3]. It (FGM) is traditionally practiced with partial or total incision or excision of the female external genitalia for a non-therapeutic reason, usually without their consent. FGM is common in Africa with varying prevalence in different countries, though the incidence is reducing due to human rights issues and tremendous advocacy for its elimination by nongovernmental organizations, it is however underreported in many African countries especially where it has been declared illegal.

This study drew a total of two hundred (200) participants to reflect the various segment of the population in Oredo 
Local Government Area of Edo sate, Nigeria. These subjects were randomly group with the adoption of both primary and secondary methods of data collection using the questionnaire and in-depth interview.

From our socio-demographics, a total of one hundred and twenty-two $122(57.5 \%)$ of sampled respondents were of the age range of 30-40 years, with $42(19.8 \%), 28(13.2 \%), 18(8.5 \%)$ and $2(0.9 \%)$ being within age brackets of 41-50, 51-60, 61-70 and $71+$ years respectively (table I). on religious believes, a total of $148(69.8 \%)$ and $26(12.3 \%)$ of sampled subjects were Christians and Muslims respectively, while African Traditional Religionists accounted for about $36(17.0 \%)$ of the total sample (table I). Also, a close look at the result reveals a $56(26.4 \%)$, $18(8.5 \%), 28(13.2 \%), 84(39.6 \%), 20(9.4 \%)$ and $6(2.8 \%)$ qualification levels of SSCE, OND, HND, B.Sc., M.Sc. and Ph.D. degrees respectively for sampled subjects; while 112 (52.8\%), 42(19.8\%), $24(11.3 \%), 16(7.5 \%)$ and $18(8.5 \%)$ of participants were Benin, Esan, Owan, Etsako and Other tribes respectively. Also, about $14(6.6 \%)$ of the participants lived in GRA, whereas, $2(0.9 \%)$ lived in Ikpoba Okha, 4(1.9\%) in Ologbo and environ, with majority $182(85.8 \%)$ in Oredo and $10(4.7 \%)$ were indigenes of Ugheli, Delta State.

Several reports have it that FGM is performed at varying age groups, from the first week of life, during infancy, before puberty, before the first childbirth and other periods in the woman's life, depending on the location and major reason underlying the practice across Africa [10]. It is usually performed individually but can be done in groups of girls or women. In Africa, specific rates from studies done by the United Nations shows it to be more in children [11]. The body further projects that over the next decade 30 million girls less than 15 years old are at risk of FGM. Within each country, there are wide differences in the types of procedure and prevalence of practice as the state specific figures reveal for the states in Nigeria [12]. These figures contrast with those obtained in 2013 for the same geopolitical zones of the country but by the fourth Nigeria Demographic and Health Survey [10].

The cultural and traditional components of FGM vary between ethnic enclaves [12]. The procedure is routinely carried out between the ages of six and eight with a few cultures preferring to cut at birth, menarche, or before marriage [9]. Mutilation is more often undergone alone, but can occur in groups, using same instruments on more than 40 women [13].

A closer look at Table II shows the obtained responses on the importance of FGM on the culture of the people. From the table, a total of $92(43.4 \%)$ of the responses believed in FGM as against the $120(56.6 \%)$ responses that opposed to it. Of these responses, about $114(53.8 \%)$ appeared to be very knowledgeable on the importance of FGM to the Benin culture as against the $98(46.2 \%)$ that were not conversant with it. From our result, a great percentage of respondents (160 of 75.5\%) supported that the people of ancient Benin kingdom strongly believe and honour their culture on the cultural practices and norms as it relates to FGM, while a lesser number of them (52 of $24.5 \%$ ) opposed to this view. This is indicative that FGM remains an important aspect of the culture of these people till recent times.

Previous reports on the prevalence of the various types of FGM varies geographically across the African continent, with Type I reportedly mostly practiced in Ethiopia, Eritrea and Kenya; while Type II appeared prevalent in regions of West Africa such as Benin, Sierra Leone, Gambia, Guinea and Nigeria [14]. Also, according to UNICEF's global databases of 2016, the practice of FGM on girls up to fourteen years old is most prevalent in Gambia (56\% of the age group), Mauritania (54\%) and Indonesia (49\%) [15]. among 15 to 49-year-old females, FGM is mostly heavily practiced in Somalia (98\%), Guinea (97\%) and Djibouti (93\%) [15]. Midwives or trained circumcisers travel across several villages, conducting the surgery without anesthesia, antibiotics or sterile equipment. 5 Although the majority of women in many of these countries now believe the practice should be ended, some still believe in the tradition. Further complicating efforts for its global eradication, the majority of girls and women in Guinea (76\%), Mali (73\%), Sierra Leone (69\%), Somalia (65\%) and Egypt (54\%) still support the tradition $[15,16]$. These reports are partly in concordance with the findings of this study.

Table IV of current study shows the social implication of FGM on the girl child. From the table, it is reported by $86(40 / 6 \%)$ of the respondents that Benin girls who are circumcised are likely to be a prostitute, 94 (44.3\%) reported they believe that girls who are not circumcised enjoy sex, while about 62 $(29.2 \%)$ reported their believe that girls who are circumcised enjoy sex, about 60(28.3\%) however reported that girls who were not circumcised stay more in their matrimonial home, $112(52.8 \%)$ reported that girls from Benin culture have choice of being circumcised, 134(63.2\%) reported that Benin parents believe more in their culture rather than the WHO about FGM, 90(42.5\%) reported that girls who are not circumcised command respects in the society, $74(34.9 \%)$ reported they have been circumcised.

Current study has revealed a significant association between FGM and female sexual function, where reduction of all aspects was obtained (namely desire, arousal, lubrication, orgasm, satisfaction and pain). Here, the total score of female sexual function for cases was significantly lower than their control of libido, implicative of more sexual drive. An Egyptian report of 2001 had proven that women with FGM have higher rates of dyspareunia with lack of sexual drive, explaining a possible predisposition to fibrosis and rigid scar tissue occasioned by narrowing of the vaginal orifice and muscular spasm to cause painful intercourse [5]. These physical factors will predispose to psychological one, where the painful experience will result into loss of sexual desire and satisfaction. Report from this study is in line with that of El-Defrawi et al., (2001) [5].

Table V shows the educational background of Bini parents who are still core practitioners of FGM. From the table, it is reported that about $68(32.1 \%)$ of the sampled respondents 
believed more in their tradition rather than their educational influences. While about 56(26.4\%) reinforced that in spite of their level of educational awareness, they still believe in FGM. About 108 (50.9\%) respondents however reported that their educational qualification changed their beliefs and practices of FGM.

An Egyptian demographic health survey of 2008 (EDHS) had reported that the possibility of FGM across African communities may decline with educational levels, hypothesizing a higher number within women in lower social strata $[17,18]$. This was also proven correct by current study as about $46 \%$ of cases had university education and more as compared with those with low social class and educational status.

\section{Conclusion}

FGM has been associated with medical, sociocultural, and economic consequences $[9,18]$. Elimination of FGM is possible through directing resources in an efficient manner. Targeted interventions can include cultural and ethnical proponents. Thus, future research should explore the effects of intervention strategies to prevent FGM.

\section{References}

1. AA Odukogbe, BB Afolabi, OO Bello, AS Adeyanju (2017). "Female genital mutilation/cutting in Africa." Translational Andrology and Urology, 6: 138-148.

2. BI Odemerho, M Baier (2012). "Female genital cutting and the need for culturally competent communication." Journal for Nurse Practitioners, 8: 452-457.

3. World Health Organization (2016). Female Genital Mutilation. http://www.who.int/mediacentre/factsheets/ fs241/en/.

4. D Moher, L Shamseer, M Clarke (2015). "Preferred reporting items for systematic review and meta-analysis protocols (PRISMA-P) statement." Systematic Reviews, 4: 2014.

5. El-Defrawi MH, Lotfy G, Dandsh F, Refaat H, Eyada M (2001). Female genital mutilation and its psychosexual impact. J Sex Marital Ther, 27: 465-473.

6. El-Zanaty F, Way AA (2009). Egypt demographic and health survey 2008. Calverton, Maryland, USA: Ministry of Health and Population [Arab Republic of Egypt], National Population Council [Arab Republic of Egypt], and ORC Macro.

7. Kandala NB, Nwakeze N, Kandala SN (2009). Spatial distribution of female genital mutilation in Nigeria. $\mathrm{Am} \mathrm{J}$ Trop Med Hyg, 81: 784-792.

8. LA Morison, A Dirir, S Elmi, J Warsame, S Dirir (2004). "How experiences and attitudes relating to female circumcision vary according to age on arrival in Britain: a study among Somalis in London." Ethnicity and Health, 9: $75-100$.

9. L Shamseer, D Moher, M Clarke (2015). "Preferred reporting items for systematic review and meta-analysis protocols (PRISMA-P): elaboration and explanation."
BMJ, 349: 7647.

10. Population Council (2016). Survey of young people in Egypt: final report. Cairo, 2005. Accessed on. Available online: http://www.popcouncil.org/pdfs/2010PGY SYPEFinalReport.pdf.

11. MDonohoe (2006). Female Genital Cutting: Epidemiology, Consequences, and Female Empowerment, http://www. medscape.com/viewarticle/546497.

12. M M Islam, MM Uddin (2001). "Female circumcision in Sudan: future prospects and strategies for eradication." International Family Planning Perspectives, 27: 71.

13. R Khosla, J Banerjee, D Chou, L Say, ST Fried (2017). "Gender equality and human rights approaches to female genital mutilation: a review of international human rights norms and standards." Reproductive Health, 14: 59.

14. Caldwell JC, Orubuloye IO, Caldwell P (2000). Female genital mutilation: conditions of decline. Popul. Res. Policy Rev, 19: 233-254.

15. Abdulcadira J, Margairaz C, Boulvain M, Irion O (2011). Effectiveness of interventions designed to prevent female genital mutilation/cutting: a systematic review. Swiss Med 6.

16. Rosen R (2000). The female sexual function index (FSFI): a multidimensional self-report instrument for the assessment of female sexual function. $J$ Sex Marital Ther, 26: 191-208.

17. Tag-Eldin MA, Gadallah MA, Al-Tayeb MN, Abdel-Aty M, Mansour E, et al. (2008). Prevalence of female genital cutting among Egyptian girls. Bull. World Health Org, 86: 269-274.

18. Al-Hussaini TK (2003). Female genital cutting: types, motives and perineal damage in laboring Egyptian women. Med Princ Pract, 12: 123-128.

Copyright: (C2021 Emily Obaide. This is an open-access article distributed under the terms of the Creative Commons Attribution License, which permits unrestricted use, distribution, and reproduction in anymedium, provided the original author and source are credited. 